\title{
EFFECT OF SUPPLEMENTING DRY YEAST OR BENTONITE AND THEIR COMBINATION AS FEED ADDITIVES ON GROWTH PERFORMANCE OF BUFFALO CALVES.
}

\author{
A. H. Ghoniem, A.A. Abdou, E.A. El-Bltagy, R. I. Moawd and A. A. H. El-Tahan \\ Animal Production Research Institute, Agricultural Research Centre, Dokki, Giza, Egypt.
}

(Received 8/11/2017, accepted 27/12/2017)

\section{SUMMARY}

$\mathrm{T}$

This study was conducted to investigate the effect of addition active dry yeast and bentonite or their mixture to buffalo calve rations on digestibility, rumen parameters, blood metabolites and growth performance. Total of twelve healthy growing buffalo calves with an average body weight of $290.83 \pm 11.90 \mathrm{Kg}$ and aged thirteen months old were used in a feeding trial lasted for 4 months as an experimental period using randomized complete block animals design and were fed individually according to Kearl requirements (1982), where $60 \%$ of their energy requirement as total digestible nutrients (TDN) was offered from concentrate feed mixture (CFM), while the other $40 \%$ of energy requirement was covered from Egyptian berseem $(\mathrm{Br})$. An extra rice straw (RS) was offered as $0.5 \%$ of animal's body weight (control ration). Animals were divided randomly into four groups (three animals per group) as follows: T1 (control ration), (T2) control ration plus yeast (10 g /animal /day), (T3) control ration plus bentonite (20 $\mathrm{g} / \mathrm{kg}$ DM intake),(T4) control ration plus bentonite ( $20 \mathrm{~g} / \mathrm{kg}$ DM intake plus yeast (10g/animal/day. The digestibility of CF, EE and NFE as well as the feeding values as TDN and DCP were almost had the same trend of DM digestibility among dietary treatments. Results of rumen parameters showed no clear trend among the dietary treatments respecting NH3-N concentration, however, almost its values of the tested rations were higher by difference degrees than that of control one. While the concentrations of TVFAs were significant higher with bentonite or yeast/bentonite rations than that of control or yeast - rations. No statistically significant differences were observed among the experimental rations for all measured blood metabolites, except that of urea- $\mathrm{N}$ was significantly $(\mathrm{p}<0.05)$ lower in group T3 and insignificant lower in groups T2 \& T3 than control. Performance of calves in terms of daily gain, total dry matter intake did not affected by supplemented yeast and bentonite or both of them to rations. While, there were significant $(\mathrm{p}<0.05)$ differences between experimental rations in feed conversion as DM and TDN intake per kg gain where the best feed conversion was associated with rations supplemented by bentonite and their mixture with yeast (T3 and T4). Similarly the beast economical efficiency was occurred with the rations (T3 and T4). Generally, from the obtained results could be concluded that the supplementation of dry yeast and bentonite or both of them to rations of buffalo calves had positive effects on digestibility, feeding value, and some rumen parameters growth performance and economic efficiency

Keywords: buffalo calves, yeast, bentonite, growth performance, digestibility, rumen parameters.

\section{INTRODUCTION}

In the Egypt, gap between the local beef production and the demand is widening calling for more efforts to increase and develop beef production. Recently feed additives are widely used in order to increase body weight gain of farm animals particularly species which well known with their slow growth rate. Bentonite mostly consists of silicon dioxide $(\mathrm{SiO} 2)$, magnesium oxide $(\mathrm{MgO})$, aluminum oxide (Al2O3) and sodium oxide (Na2O) (European food safety authority (EFSA, 2014). Bentonite recognized as safe for feeding to livestock (EFSA, 2016), and it's as feed additives for all animal species has been proposed. EFSA (2011) recommended a maximum level of $0.5 \%$ bentonite to be safe for all animal species in despite of the inconsistency in the currently available data. The inclusion of $0.1 \%$ and $0.3 \%$ 


\section{Ghoniem et al.}

bentonite in a diet has an influence on final body weight, total body weight gain, and daily gain compared with the un-supplemented diets (Kim Young et al., 2017). It can absorb toxic products of digestion and decreases the accumulation of toxic substances in tissues, thus decreasing the incidence of internal disorders.(Mckenzie, 1991). Bentonite is a natural clay that comes from volcanic ash and consists mainly of montmorillonite with minor amount of illite, kaolinite, cristobalite and other minerals (Adamis et al. 2005). Bentonite, like other clay materials is a crystalline aluminosilicates characterized by its ability to exchange cations without major changes in structure; it is used in ruminant animal diets to improve digestibility of nutrients Salem et al. (2001), Mohsen and Tawfic (2002), Gabr et al. (2003) and Hassan (2009) and increased daily body gain as reported by Kang et al. (2002), Berthiaume et al. (2007). Using yeast culture in ruminant diets can improve the animal performance. Dawson et al. (1990) reported that yeast culture increased ruminal cellulose digestion and consequently improved feed efficiency and growth performance of ruminant animals. Also, increased microbial growth in the rumen and enhanced microbial protein synthesis. Several reasons for improvements in ruminal fermentation by feeding YC have been suggested. The results of numerous studies indicate that Saccharomyces cerevisiae dried brewer's yeast enhances animal productivity and their health conditions (Dobicki et al, 2007, Milewski, 2009, Gopalakannan and Arul 2010). In effective and nutritionally well-balanced animal diets, essential nutrients are often combined with feed additives and supplements that contain microorganisms and their products (Grela and Semeniuk, 2006). The addition of bentonite and probiotics to the diet of Hanwoo steers increased concentrations of trace minerals $(\mathrm{Zn}, \mathrm{Cu}$, and $\mathrm{Fe})$ in the longissimus muscle of steers and in conclusion, the combined use of mineral clay and probiotics in the animal diet could be improved mineral retentions in muscle without any deleterious effects on carcass traits of steers (Wan-Sup et al., 2012). However, little information and results are available on the effect of feeding bentonite and probiotics together (associative effect) on the growth performance of beef cattle.

It is, therefore, postulated that the addition of probiotics with bentonite might show a desirable effect on meat quantity and quality. Based on the previous reports of the effects of bentonite and probiotic incorporated into diets of ruminants, a study was conducted to evaluate the effects of these dietary additives on productive performance by buffalo calves in Egypt.

\section{MATERIALS AND METHODS}

\section{The experimental procedures:}

This study was carried out at El-Gemmaiza Research Station which is belonging to Animal Production Research Institute, Agricultural Research Centre, Egypt. Twelve healthy growing buffalo calves with an average body weight of $290.83 \pm 11.9 \mathrm{Kg}$ and age thirteen months were used in feeding trial that lasted for four months. Animals were divided randomly into four similar groups (three animals per group) as follows:

Control ration (T1): 60\% CFM plus 40\% Egyptian berseem (Br) based on total digestible nutrients (TDN) requirements in additions of $0.5 \%$ of animal's body weight from RS. While, Ration T2 received control ration plus bentonite $(20 \mathrm{~g} / \mathrm{kg} \mathrm{DM})$, Ration $\mathrm{T} 3$ received control ration plus yeast (10 $\mathrm{g} / \mathrm{animal}$ /day), and Ration T4 received control ration plus bentonite (20 g/kg DM) and yeast (10 g /animal /day). Animals were fed individually according to Kearl requirements (1982) and bentonite and yeast (Doxal,DXThepax100R(strain GSH351) containing 5x109 cells / g (European patent n.0111202 - European patent n.98116181.3) were offered mixed with concentrate feed mixture. At the beginning, all animals were drenched drugs against internal parasites. Roughage portion was offered once daily, while CFM was offered twice daily, and animals were watered twice a day. Amount of feeds was adjusted biweekly according to growth rate changes and feed efficiency was also calculated.

\section{Nutrients Digestibility and Rumen Parameters:}

At the end of feeding trial, all animals were used for digestibility trail to determine the digestibility coefficients and feeding values of experimental rations using Acid Insoluble Ash (AIA) procedure as a natural marker according to Van Keulen and Young (1977). Fecal grab samples of about 500g were taken from the rectum three times for five days as collection period. At the end of collection period of the digestibility trial, rumen liquor was withdrawn using stomach tube before morning feeding (zero time), 3 and $6 \mathrm{hr}$ after feeding. The $\mathrm{pH}$ value was measured immediately using portable $\mathrm{pH}$ meter. The rumen liquor samples were filtered through three layers of cheese cloth. Then rumen liquor samples were put in plastic bottles and preserved by using few drops of toluene and paraffin oil and kept at $-20{ }^{\circ} \mathrm{C}$ for determination of total volatile fatty acids and ammonia- nitrogen. at the same time, blood samples were 
taken from the jugular vein of the animals of the digestibility trial before morning feeding. Blood serum was preserved to measure some blood parameters.

\section{Chemical Analysis:}

Proximate analysis for dry matter (DM), crude protein (CP), crude fiber (CF), ether extract (EE) and ash of feeds, feed refusals and feces were determined according to the official methods A.O.A.C. (2000). Rumen Ammonia-N was determined according to the modified semi-micro Kijeldehl digestion method A.O.A.C. (1995). Total volatile fatty acids were determined according to Eadie, et al., (1967). Blood serum was separated from the whole blood to determine the total protein, albumin and urea-N. using commercial kits of Bio-Merieus, lab, France. Globulin was determined by difference.

\section{Statistical analyses:}

A statistical analysis was carried out by General Linear Model procedures (GLM) described in SAS User's Guide (SAS 2003). Differences among treatment means were separated by Duncan's new multiplerange test (Duncan, 1955).

\section{RESULTS AND DISCUSSION}

\section{Chemical composition of experimental feeds:}

The chemical composition of ingredients of experimental rations are presented in Table (1). The proximate analysis of $\mathrm{Br}$ and $\mathrm{RS}$ used in this study were extremely comparable to those recorded in the literature. The values of CP (14.25\%), CF (14.22\%) and EE (3.46\%) of CFM were also within the normal range of the currently manufactured concentrates in Egypt, which usually used for meat production.

Table (1): Chemical composition of ingredients and calculated composition of experimental rations (on DM basis).

\begin{tabular}{lccccccc}
\hline Item & \multicolumn{7}{c}{ Chemical composition } \\
\cline { 2 - 8 } & DM & OM & CP & CF & EE & NFE & Ash \\
\hline $\begin{array}{l}\text { Proximate analysis } \\
\begin{array}{l}\text { Concentrate feed } \\
\text { (CFM)* }\end{array}\end{array}$ mixture & 92.15 & 86.24 & 14.25 & 14.22 & 3.46 & 54.31 & 13.76 \\
Rice straw (R.S) & 91.45 & 77.62 & 4.45 & 36.29 & 0.63 & 36.25 & 22.38 \\
Berseem (Br) & 15.35 & 82.25 & 10.53 & 28.36 & 0.83 & 42.53 & 17.75 \\
Calculated composition of experimental rations & & & & & \\
T1 (control) & 63.64 & 83.09 & 10.97 & 23.73 & 1.94 & 46.45 & 16.91 \\
(T2) & 65.61 & 83.77 & 11.72 & 21.90 & 2.19 & 47.96 & 16.23 \\
(T3) & 65.03 & 82.62 & 11.47 & 22.04 & 2.12 & 46.99 & 17.38 \\
(T4) & 65.64 & 82.58 & 11.37 & 22.24 & 2.10 & 46.87 & 17.42
\end{tabular}

*CFM; contained $37 \%$ yellow corn, $30 \%$ undecorticated cotton seed, $20 \%$ wheat bran, $6.5 \%$ rice bran, $3 \%$ molasses, $2.5 \%$ limestone, $1 \%$ common salt.

\section{Nutrient digestibility and feeding values:}

Results indicated that the daily dry matter intake (DMI) as $\mathrm{kg} / 100 \mathrm{~kg} \mathrm{B.W}$ was insignificantly lower with the three tested rations (T2, T3 and T4) than that of control one (T1). Also, similar trend regarding DMI as $\mathrm{g} / \mathrm{kg} \mathrm{w}^{0.75}$ was occured among dietary treatments (Table 2). These results are in agreement with those obtained by El-Tahan et al. (2005) who observed lack of significant effect on dry matter intake due to supplemented the rations of growing calves with 2 or $4 \%$ tafla. Also, similar results were obtained by Saleh et al. (1999) who indicated that DM intake by lactating buffaloes slightly decreased in bentonite groups. Otherwise, Abou '1 Ella (2007), found that DMI of lactating ewes had a significant increased with 


\section{Ghoniem et al.}

rations supplemented with dried yeast and/or bentonite compared to the control ration that free from both supplements.

Table (2): Feed intake, digestibility and feeding nutritive values of the experimental rations by buffalo calves.

\begin{tabular}{|c|c|c|c|c|}
\hline Item & T1 & $\mathrm{T} 2$ & T3 & $\mathrm{T} 4$ \\
\hline \multicolumn{5}{|l|}{ DM intake : } \\
\hline $\mathrm{Kg} / 100 \mathrm{~kg} \mathrm{B.W}$ & $3.55 \pm 0.09$ & $3.27 \pm 0.14$ & $3.28 \pm 0.10$ & $3.36 \pm 0.28$ \\
\hline $\mathrm{g} / \mathrm{Kg} \mathrm{W}^{0.75}$ & $154.92 \pm 3.85$ & $140.81 \pm 3.54$ & $141.64 \pm 2.38$ & $145.17 \pm 2.51$ \\
\hline \multicolumn{5}{|c|}{ Digestion coefficients $\%$ : } \\
\hline DM & $73.72^{\mathrm{b}} \pm 0.09$ & $74.27^{\mathrm{b}} \pm 0.34$ & $74.30^{\mathrm{b}} \pm 0.19$ & $78.00^{\mathrm{a}} \pm 0.47$ \\
\hline $\mathrm{OM}$ & $77.08^{\mathrm{b}} \pm 0.54$ & $76.14^{\mathrm{b}} \pm 0.37$ & $76.88^{\mathrm{b}} \pm 0.60$ & $79.44^{\mathrm{a}} \pm 0.30$ \\
\hline $\mathrm{CP}$ & $75.10^{c} \pm 0.29$ & $74.60^{c} \pm 0.26$ & $77.87^{\mathrm{b}} \pm 0.55$ & $79.87^{\mathrm{a}} \pm 0.55$ \\
\hline $\mathrm{CF}$ & $60.38^{\mathrm{b}} \pm 0.74$ & $61.88^{\mathrm{b}} \pm 0.45$ & $64.87^{\mathrm{a}} \pm 0.43$ & $65.08^{\mathrm{a}} \pm 0.49$ \\
\hline $\mathrm{EE}$ & $65.75^{\mathrm{b}} \pm 0.68$ & $72.83^{\mathrm{a}} \pm 0.53$ & $77.76^{\mathrm{a}} \pm 0.28$ & $78.37^{\mathrm{a}} \pm 0.40$ \\
\hline NFE & $84.10^{\mathrm{ab}} \pm 0.53$ & $83.06^{\mathrm{b}} \pm 0.29$ & $84.30^{\mathrm{ab}} \pm 0.80$ & $86.11^{\mathrm{a}} \pm 0.96$ \\
\hline \multicolumn{5}{|c|}{ Feeding values (\%, DM basis) : } \\
\hline TDN & $65.61^{\mathrm{b}} \pm 0.11$ & $65.75^{\mathrm{b}} \pm 0.63$ & $65.58^{\mathrm{b}} \pm 0.56$ & $67.65^{a} \pm 0.43$ \\
\hline $\mathrm{DCP}$ & $8.25^{\mathrm{b}} \pm 0.12$ & $8.72^{\mathrm{a}} \pm 0.12$ & $8.93^{\mathrm{a}} \pm 0.20$ & $9.06^{\mathrm{a}} \pm 0.12$ \\
\hline
\end{tabular}

The enhanced intake is most likely due to on improvement of the rate of breakdown of feeds in the rumen. The digestibility of DM, OM and CP were significantly $(\mathrm{p}<0.05)$ increased when buffalo calves fed T4 ration compared to those which fed T1,T2 or T3 (Table 2). However, the digestibility of EE was significantly $(p<0.05)$ higher with all tested ration than that of control one. compared with other groups. Also, CF digestibility was significantly $(\mathrm{p}<0.05)$ higher with T3 and T4 than that of T1 and T2. The digestibility of NFE did not significantly affected by supplemented rations with yeast and/or bentonite in comparison with the un-supplemented one (control). The feeding values as TDN showed significantly $(\mathrm{p}<0.05)$ increase by buffalo calves fed $\mathrm{T} 4$ ration compared with other groups, but there were no significant among other groups. While the values of DCP were significantly $(\mathrm{p}<0.05)$ higher when animals fed the tested rations (T2, T3 and T4) than those fed control ration. These results are in agreement with those reported by Helal and Abdel - Rahman (2010), Abd El-Ghani, (2012), Kumar et al. (2013) and Aazami et al. (2017). Also, results here are in line with those reported by Abou'l Ella (2007) who found that most nutrients digestibilities and feeding values were significantly higher with ration supplemented with both dried yeast and bentonite (together) than those of ration that free from these supplements. Additionally the same author proved that the together supplements gave insignificantly better digestibility and feeding values than if each one given in individual case. Earlier, El -Tahan et al. (2005) found similar results to those of the current study respecting digestion coefficients and feeding values when fed growing calves on rations supplemented with $2 \%$ or $4 \%$ tafla clay. However, yeast/ yeast cultures had been used as supplements in animal feeds for long time ago and numerous studies proved its greatly positive effects on the digestibility and feeding values of ruminants' rations (El -Ashry et al 2001, Mousa et al. 2012 and Habeeb, 2017). Lastly it could be emphasized that the effects of together yeast and bentonite supplementation have an advantage over the use of each one alone in the rations of ruminant animals. Undoubtedly there is a kind of positive associative effects between the two supplements and even with the other ingredients of the rations, and as a result, it reflected positively on feed utilization and the productive performance of the experimental animals.

\section{Rumen parameters:}

The results of ruminal parameters are presented in (Table 3). The results of ruminal $\mathrm{pH}$ values before feeding showed that $\mathrm{T} 2$ had significantly $(\mathrm{p}<0.05)$ higher values $(7.80)$ compared with that of $\mathrm{T} 3$, T4, but there were no significant difference between T2 and control (T1) ration, the lowest value was obtained with T4 ration (7.37). But, the results of ruminal $\mathrm{pH}$ values at 3 and $6 \mathrm{hrs}$. after feeding showed insignificant differences among the dietary treatments. Similar results were reported by, Helal and AbdelRahman (2010), Habeeb (2017) and Mohsen Kazemi et al. (2017) who evaluated the effect of supplemented yeast or bentonite on some rumen parameters of farm animals. 
The results of $\mathrm{NH}_{3}-\mathrm{N}$ concentration values showed lower $\mathrm{NH} 3-\mathrm{N}$ concentration values before feeding (zero time) compared with 3 and 6 hrs. after feeding. However, over the three sampling times, three were no clear trend respecting ammonia-N concentration values among the experimental dietary treatments. But almostly the concentration of $\mathrm{NH} 3-\mathrm{N}$ was higher by different degree than that of control rations that have the lowest NH3-N values over all sampling times. The highest values was obtained with $\mathrm{T} 3$ at zero sampling time and also with T2 at $3 \mathrm{hrs}$ sampling time and with T4 at $6 \mathrm{hrs}$ sampling time. The variation in the concentrations of NH3-N among treatments over the different sampling times might be due to the numerous factors which exceedingly affecting rumen fermentative parameters. The fluctuation of NH3-N concentration of yeast treatment may be attributed to the inhibitory effect of some growth promoters on proteolysis and ruminal urease enzyme activity and also the rate of incorporation of ammonia into microbial protein synthesis. The result obtained by Abou 'l Ella (2007) revealed that no significant effects in NH3-N concentration due to supplementing the lactating ewe's rations by either dry yeast or bentonite or their dry yeast or bentonite or their mixture. These results are in agreement with those of Aguilera Soto et al. (2009), and Abd El-Ghani, ((2012).

Table (3): Effect of feeding the experimental rations on rumen liquor parameters.

\begin{tabular}{lcccc}
\hline Item & \multicolumn{3}{c}{ Treatments } & T4 \\
\cline { 2 - 4 } & T1 & T2 & T3 & \\
PH & $7.00^{\mathrm{ab}}$ & $7.20^{\mathrm{a}}$ & $6.90^{\mathrm{b}}$ & $6.77^{\mathrm{b}}$ \\
Zero & 6.6 & 6.20 & 6.85 & 6.55 \\
3hrs & 6.85 & 7.00 & 6.90 & 7.05 \\
6hrs & & & \\
NH3-N(mg/100 ml) & $7.29^{\mathrm{c}}$ & $9.79^{\mathrm{b}}$ & $14^{\mathrm{a}}$ & $7.83^{\mathrm{bc}}$ \\
Zero & $15.87^{\mathrm{c}}$ & $32.32^{\mathrm{a}}$ & $24.27^{\mathrm{b}}$ & $17.62^{\mathrm{c}}$ \\
3hrs & $8.17^{\mathrm{c}}$ & $28.58^{\mathrm{b}}$ & $29.40^{\mathrm{ab}}$ & $30.57^{\mathrm{a}}$ \\
6hrs & & & $13.07^{\mathrm{a}}$ \\
TVF's (meq/100ml) & $7.27^{\mathrm{b}}$ & $8.95^{\mathrm{b}}$ & $138^{\mathrm{a}}$ & $14.72^{\mathrm{b}}$ \\
Zero & $16.32^{\mathrm{b}}$ & $11.52^{\mathrm{c}}$ & $19.28^{\mathrm{a}}$ & $12.88^{\mathrm{a}}$ \\
3hrs & $8.60^{\mathrm{c}}$ & $10.87^{\mathrm{b}}$ & $13.65^{\mathrm{a}}$ &
\end{tabular}

$($ Control $) T 1=60 \% \quad C F M+40 \%$ BR + R.S., T2=60\% CFM+40\% BR+R.S. + yeast T3=60\% CFM+40\% BR+R.S. + Bentonite and $T 4=60 \% C F M+40 \%$ BR + R.S. + yeast + Bentonite.

Concerning, the results of TVFA,s overall sampling times, the bentonite - rations has achieved the highest value o TVFAs among the experimental treatments, being the differences were mostly significant between the bentonite- rations (T3) vs. both yeast- ration and control one, while the differences not significant between T3 and T4 over the most sampling times (zero and $6 \mathrm{hrs}$ ones). The present results are in harmony with those obtained by Abou 'l Ella (2007) who demonstrated that TVFAs concentrations behaved similar trend to that of the current study among treatments of zero supplement (control), yeast, bentonite or their mixture of lactating ewes, ration, the differences among these ration did not significant, El-Tahan et al; (2005) found similar trend when supplementing ration of growing calves with tafla clay at $2 \%$ or $4 \%$ of the silage portion in their ration. In the same trend, results of Helal and Abdel-Rahman (2010), Abd El-Ghani, (2012) and Aazami et al. (2017) were obtained.

\section{Blood Parameter:}

The results of Total protein, albumin, globulin and urea, are presented in (Table 4). The mean values of serum total protein, albumin, globulin and albumin/globulin ratio showed insignificant differences among all treatments. The mean values of serum total protein and globulin showed the highest values with control (T1), but T4 recorded highest values of albumin and albumin/ globulin ratio. The results of serum urea concentration showed significant lower $(\mathrm{P}<0.05)$ value with bentonite - ration $(\mathrm{T} 3)$ than that insignificant lower values of control ration (T1). These results were similar of those found by Sangmo lee et al. (2010), Helal and Abdel - Rahman (2010), Wan Sup et al. (2012) and Mohsen Kazemi et al. (2017). In relation to the present results similar values of blood total protein content was recorded by Salem and El-Shewy (2001) when fed the lactating goats with rations supplemented with zero (control), 3\% bentonite or $3 \%$ dolomite, $6.57,6.70$ and $6.66 \mathrm{~g} / 100 \mathrm{ml}$ respectively. In consistent with the present results, 


\section{Ghoniem et al.}

Abou '1 Ella (2007) revealed that insignificant differences in respect of the concentrations of most blood metabolites measured (TP, Gl, AL / Gl ratio and urea) among the dietary treatments in which using supplements of zero (control, $0.5 \%$ yeast, $4 \%$ bentonite or their mixture, with lactating ewes' rations.

Table (4): Effect of feeding the experimental rations on blood parameters of buffalo calves.

\begin{tabular}{lllll}
\hline Item & \multicolumn{4}{c}{ Treatments } \\
\cline { 2 - 5 } & $\mathrm{T} 1$ & $\mathrm{~T} 2$ & $\mathrm{~T} 3$ & $\mathrm{~T} 4$ \\
\hline Total protein $(\mathrm{g} / \mathrm{dl})$ & $6.70 \pm 0.08$ & $6.31 \pm 0.22$ & $6.46 \pm 0.16$ & $6.34 \pm 0.12$ \\
Albumin $(\mathrm{g} / \mathrm{dl})$ & $3.45 \pm 0.11$ & $3.57 \pm 0.03$ & $3.47 \pm 0.08$ & $3.64 \pm 0.06$ \\
Globulin $(\mathrm{g} / \mathrm{dl})$ & $3.25 \pm 0.20$ & $2.74 \pm 0.20$ & $2.99 \pm 0.17$ & $2.70 \pm 0.14$ \\
Albumin/globulin & $1.07 \pm 0.10$ & $1.30 \pm 0.08$ & $1.16 \pm 0.08$ & $1.36 \pm 0.08$ \\
Urea-N (mg/dl) & $59.57^{\mathrm{a}} \pm 1.30$ & $55.83^{\mathrm{ab}} \pm 1.84$ & $48.87^{\mathrm{b}} \pm 0.78$ & $54.43^{\mathrm{ab}} \pm 1.02$ \\
\hline
\end{tabular}

$a, b$ and $c$ means the same row with different superscripts differ $(P<0.05)$.

$($ Control $) T 1=60 \%$ CFM $+40 \%$ BR + R.S., T2=60\% CFM+40\% BR+R.S. + yeast, $T 3=60 \% C F M+40 \%$ BR + R.S. + Bentonite and T4=60\% CFM+40\% BR+ R.S. + yeast + Bentonite.

\section{Growth Performance:}

The results of the daily gain (Table 5) showed that the highest value was recorded with T3 treatment followed by $\mathrm{T} 4$ and then control ration (T1), while the lowest value was observed with $\mathrm{T} 2$, but the differences between all treatments were not significant. The data clearly showed that dietary supplementation with bentonite improved growth performance of buffalo calves. In the current study, the improvement in growth performance might be due to the interaction bentonite and its favorable modulatory effect which resulted in the enhanced of nutrients digestibility owing to a the delay in the passage of food Particles through the gut. Similar trend was obtained by Berthiaume et al. (2007), Lee et al. (2010) and Habeeb (2017. In matching with the current results, Abdel-Baki et al. (2001) found insignificant different respecting total gain and daily gain of crossbred Friesian calves fed diets without or with urea-tafla supplement being $168.41 \mathrm{vs.} 168.29 \mathrm{~kg}$ as total gain and $0.752 \mathrm{vs} .0 .715 \mathrm{~kg}$ as daily AlHamed et al. (2007) regarding total gain and daily gain were significant decreased when Awassi lambs fed diets supplemented with either 5\% zeolite or 5\% bentonite in comparison with the unsupplemented one. Otherwise, El-Tahan et al. (2005) found that growth rate of Friesian crossbred calves was significant increased with supplementation their diets with $2 \%$ or $4 \%$ tafla supplement. Also, milk yield of ewes was significant higher with supplemented their rations with $0.5 \%$ dry yeast, $4 \%$ bentonite and their mixture (Abou 'l Ella (2007).

Presumably, the explain of the modulatory effect of these supplements where such compounds have great capability to reduce the rate of passage of the digesta in the rumen and consequently increases the opportunity for absorption the nitrogen and also save the favorable ruminal environment for microorganisms for more utilization of dietary nutrients and all these vital processes could be positively reflected on the host animals in which the end products (particularly $\mathrm{N}$ - compounds), being enough available and then reaching by high level into the animal tissues (Salem et al. 2001). These findings are in disagreement with the results of Mohsen Kazemi et al. (2017) and Kim Young et al. (2017) who found that the inclusion of $0.1 \%$ and $0.3 \%$ bentonite in the diets of steers has significant $(\mathrm{p}<0.05)$ influence on final body weight, total body weight gain, and daily gain compared with the control. The values of total DM, TDN and DCP intake as $(\mathrm{kg} / \mathrm{h} / \mathrm{d})$ of the experimental rations are presented in (Table 5). The results of dry matter intake (DMI) and DCP intake as $(\mathrm{kg} / \mathrm{h} / \mathrm{d})$ showed no significant differences among all experimental rations. The highest value of dry matter intake was obtained with control (T1) (12.91 $\mathrm{kg} / \mathrm{h} / \mathrm{d})$, while the lowest values were recorded with $\mathrm{T} 3(11.26 \mathrm{~kg} / \mathrm{h} / \mathrm{d}) \mathrm{T} 2$ and $\mathrm{T} 4 \mathrm{rations}$ had no intermediate values being 11.35 and 11.51 respectively. However, the results of TDN intake was significantly $(\mathrm{P}<0.05)$ decreased when animals fed the supplemented rations compared to those fed the control one, with no significant differences among the tested rations. Otherwise, the DCP intake did affected significantly by dietary treatments. In relation to this point, Abu-Zanat (1997) and Al-Hamed et al. (2007) found that when using clay supplements (Zeolite and bentonite) could be decline the palatability of rations and in turn decreasing feed intake, where, they were observed some feed residue in trough due to the mentioned supplements. The results of feed conversion that expressed as TDN, DCP and DM feed unites intake per $1 \mathrm{~kg}$ gain are presented in (Table 5). The results of feed conversion as DM and TDN per kg gain showed significant $(\mathrm{P}<0.05)$ improvement with all tested rations in comparison with control one. Similar trend was occurred in case of DCP: gain among treatments, with the best feed conversion being associated with the bentonite-ration T3) the results are in harmony with those reported 
by El-Tahan (2005) who indicated that the feed conversion of feed consumed as DM, TDN AND DCP gain was markedly improved with supplementing rations of growing calves with $2 \%$ or $4 \%$ tafla compared with unsupplemented one. These results are in harmony with those reported by Aghashahi et al (2005), Helal and Abdel-Rahman (2010) and Mohsen Kazemi et al. (2017). The results of the economic efficiency showed that the calculated feed cost $/ \mathrm{kg}$ gain for the tested rations were clearly lower than of control one. The daily profit values were11.50, 11.28, 18.07 and 15.11 L.E /kg gain for T1, T2, T3 and T4 and also the improvement based on control ration (100\%) were 98.09, (157 and 131\% for the tested ration groups (T2, T3 and T4), respectively. These results are in harmony with those obtained by ElTahan et al. (2005) Hassan (2009), Abd El-Baki et al. (2009) and Abd El-Ghani, (2012).

Table (5): Effect of feeding the experimental rations on productive performance of buffalo calves.

\begin{tabular}{|c|c|c|c|c|}
\hline Items & $\mathrm{T} 1$ & $\mathrm{~T} 2$ & T3 & $\mathrm{T} 4$ \\
\hline Initial weight, $\mathrm{kg}$ & $306.70 \pm 13.33$ & $293.3 \pm 35.28$ & $280 \pm 27.54$ & $283.30 \pm 26.82$ \\
\hline Final weight, kg & $422 \pm 13.02$ & $405.0 \pm 45.37$ & $405.0 \pm 18.93$ & $403 \pm 26.19$ \\
\hline Total body gain, $\mathrm{kg}$ & $115.30 \pm 7.64$ & $111.70 \pm 13.02$ & $125 \pm 8.66$ & $119.70 \pm 2.98$ \\
\hline Daily gain, (kg) & $0.96 \pm 06$ & $0.93 \pm 0.11$ & $1.04 \pm 0.07$ & $1.00 \pm 0.02$ \\
\hline \multicolumn{5}{|c|}{ Daily feed intake, $(\mathrm{kg} / \mathrm{h} / \mathrm{d})$ as fed: } \\
\hline CFM & 6.10 & 5.96 & 5.71 & 5.79 \\
\hline Berseem (BR) & 33.50 & 28.50 & 28.62 & 28.85 \\
\hline Rice straw (R.S) & 2.35 & 1.63 & 1.56 & 1.70 \\
\hline Bentonite & 00 & 00 & 0.20 & 0.20 \\
\hline Yeast & 00 & 0.01 & 00 & 0.01 \\
\hline \multicolumn{5}{|l|}{ Total intake $(\mathrm{kg} / \mathrm{h} / \mathrm{d})$} \\
\hline $\mathrm{DM}$ & $12.91 \pm 0.50$ & $11.35 \pm 0.94$ & $11.26 \pm 0.50$ & $11.51 \pm 0.74$ \\
\hline TDN & $8.47^{\mathrm{a}} \pm 0.02$ & $7.45^{\mathrm{b}} \pm 0.26$ & $7.38^{\mathrm{b}} \pm 0.11$ & $7.79^{\mathrm{b}} \pm 0.23$ \\
\hline $\mathrm{DCP}$ & $1.07 \pm 0.07$ & $0.99 \pm 0.11$ & $1.01 \pm 0.12$ & $1.04 \pm 0.09$ \\
\hline \multicolumn{5}{|c|}{ Feed conversion ( $\mathrm{kg}$ feed/kg gain): } \\
\hline $\mathrm{DM}$ & $3.45^{\mathrm{a}} \pm 0.211$ & $12.18^{\mathrm{b}} \pm 0.45$ & $10.83^{\mathrm{c}} \pm 0.27$ & $11.51^{b c} \pm 0.15$ \\
\hline TDN & $8.82^{\mathrm{a}} \pm 0.21$ & $8.02^{\mathrm{ab}} \pm 0.30$ & $7.10^{\mathrm{b}} \pm 0.21$ & $7.79^{b} \pm 0.39$ \\
\hline $\mathrm{DCP}$ & $1.11 \pm 0.12$ & $1.07 \pm 0.09$ & $0.97 \pm 0.12$ & $1.04 \pm 0.09$ \\
\hline \multicolumn{5}{|l|}{ Economic efficiency } \\
\hline Price of daily gain, L.E & 46.08 & 44.64 & 49.92 & 48.00 \\
\hline Daily feed cost, L.E & 34.58 & 33.36 & 31.85 & 32.89 \\
\hline Feed cost $/ \mathrm{kg}$ gain, L.E & 36.02 & 35.87 & 30.63 & 32.89 \\
\hline Daily profit, L.E & 11.50 & 11.28 & 18.07 & 15.11 \\
\hline Improvement, \% & 100 & 98.09 & 157 & 131 \\
\hline
\end{tabular}

From these results, it could be concluded that adding bentonite and /or yeast to rations of buffalo calves were more effective in decreasing the feed cost to produce $1 \mathrm{~kg}$ live body weight than control.

\section{CONCLUSION}

It could be concluded that the supplementation of dry yeast and bentonite or both of them to rations of buffalo calves had positive effects on digestibility, feeding values, some rumen parameters and growth performance, beside better economic efficiency. In addition, the results obtained for the bentonite with yeast were not clear enough. So, we need to continue the researches on this point with different doses for both yeast and bentonite.

\section{REFERENCES}




\section{Ghoniem et al.}

A.O.A.C. (1995).Official Methods of Analysis 15th ed. Association of Official Analytical Chemists. Arlington, Virginia, USA.

A.O.A.C. (2000). Association of Official Analytical chemists. Official Methods of Analysis Washington, D, C., USA.

Aazami, $\quad$ M.H.; A.M. Tahmasbi; $\quad$ V. Forouhar and A.A. Naserian (2017). Effects of Sodium Bentonite on Blood Parameters, Feed Digestibility and Rumen Fermentation Parameter, of Male Balouchi Sheep Fed Diet Contaminated by Diazinon, an Organophosph ate Pesticide. Iranian J. of Applied Anim., Sci., 7 (3), 421-428.

Abd El-Baki, S.M.; E.A. Hassona; H.M. Ghenem; H.M. Yousef; A.A. Zaki; R.I. Moawd and S.A. Ebrahem (2001). Clays in animal nutrition. 7- Effect of feeding ensiled sulphuric acid-urea-tafla treated rice straw by crossbred Friesian bull calves on digestibility, growth performance and some physiological parameters Egypt . J. Nutr. and Feeds, 4 (1): 1-9.

Abd El-Baki, S.M.; S.M. Bassuny; S.A. Shehata; H.M. Ghanem and A.H. Ghoneim (2009). Effect of using treated rice straw by urea ,sulphuric acid and tafla clay on performance of sheep and lactating buffalos. Zagazig J .Agric. Res., 36 (3):559-581.

Abd El-Ghani, H. Ghoneim, (2012). Nutritional studies on ruminant fed tafla clay with green forage. Ph.D. Thesis, Faculty of Agric., Zagazig Univ.

Abou ,1 Ella A.A. (2007). Effect of dry yeast and/or bentonite as feed additives on the productive performance of lactating ewes and its offsprinkings. Egypt . J. Nutr. and Feeds, 10 (1) : 81-98.

Abu-Zanat, M. (1997), using natural zeolite in the fattening rations of Awassi lambs Drasat, Agri. Sci. 24 (2) : 268-274.

Adamis, Z.; J. Fodor and R.B. Williams (2005). Bentonite, Kaolin and Selected Clay Minerals. World Health Organization, Geneva, Switzerland, ISBN: 92-4-157231.

Aghashahi A.R.; S.A Mirhadi; and M. MoradishahreBabak (2005). Effects of natural bentonite (Montmorillonite), processed bentonite and clinopetilolite-rich tuff on the fermentation parameters, rumen microbial population and feedlot performance in male calves. Irnian J. Agric. Sci. 36,3-10.

Aguilera Soto, J.I.; R.G. Ramirez; C.F. Arechiga; M.L. lorente; M.A. Lopez-Carlos; J.A. Pina-Flores; C.A. Medina-flores; H. Rodriguez Frausto; D. Rodriguez-Tenorio and H. Gutierrez-Banuelos (2009). Effect of feed additives on digestibility and performance of Holstein cows fed wet brewers grains. J. Appl. Anim. Res., 36: 227-230.

Al - Hamed, D; A Hamra and K. Gwasra. (2007).Effect of treatments by bentonite and zeolite on some sexual characteristics of Awassi meal sheep. Egypt. J. Nutr. and Feeds, 10 (2) Sp. Iss :387-399.

Berthiaume, R.; M. Ivan; and C. Lafrenière (2007). Effect of sodium bentonite supplements on growth performance of feedlot steers fed direct-cut or wilted grass silage based diets. Canadian J. of Anim. Sci., 87(4), 631-638.

Dawson, K. A.; Newman, K. E. and Boling, J. A. (1990). Effects of microbial supplements containing yeast and lactobacilli on roughage-fed ruminal microbial activities. J. Anim. Sci., 68 : 3392 - 3398.

Dobicki A.; J. Preś; A.; Zachwieja R. Mordak and W. Jakus (2007). Influence of yeast preparations on chosen biochemical blood parameters and the composition of cow milk. Med Wet 2007; 63: 955-959.

Duncan, D.B.; (1955). Multiple ranges and Multiple F. test. Biometrics, 11:1-42.

Eadie, J. M.; P. N. Hobson and S. O. Mann (1967). A note on some comparison between the rumen content of barley fed steers and that young calves also fed on high concentrate rations. J. Anim. Prod., 9:247.

EFSA (European Food Safety Authority) Journal (2016). Safety and efficacy of a natural mixture of illite, montmorillonite and kaoliniteas a feed additive for all animal species EFSA J. 14:4342-4360.

EFSA Journal (2011). Efficacy of bentonite for all species. EFSA Journal 2011; 9 (6):2276 [9 pp.].

EFSA Journal. (2014).Scientific Opinion on the safety and efficacy of Fried land clay (montmorilloniteillite mixed layer clay) when used as technological Additive for all animal species. EFSA J. ;12(11):3904 
El-Ashry, M.; A. Zaba A. Motagally and Y. A. Maareck (2001). Effect of live dried Baker's yeast and yeast culture on performance of growing buffalo calves. Egypt. J. Nutr. and Feeds 4 (special Iss) 607617.

El-Tahan, A. A. H.; R. I. Moawd; A. A. Zaki and M. Marghany. (2005). Effect of adding tafla clay on performance of growing calves fed rations containing maize silage. Egypt. J. Nutr. and Feeds .8(1) Special Iss. :(167-178).

Gabr, A.A.; E.I. Shehata M.E. Ahmed and M.H. Azzam (2003). Performance and carcass traits of Rahmani lambs fed rations containing dried poultry manure with addition of bentonite clay. Egypt. J. of Nutr. and Feeds, 6: 2, 173-188.

Gopalakannan A.; and V. Arul (2010). Enhancement of the innate immune system and disease-resistant activity in Cyprinuscarpio by oral administration of $\beta$-glucan and whole cell yeast. Aquac Res 2010; 41: 884-892.

Grela, E.R;. and V. Semeniuk (2006). Consequences of the withdrawal of antibiotic growth promoters from animal feeding. Medycynaweterynaryjna 62(5):502-507 .

Habeeb, A.A.M (2017). Importance of Yeast in Ruminants Feeding on Production and Reproduction. Ecology and Evolutionary Biology. Vol. 2, No. 4, 2017, pp. 49-58.

Hassan, E.H.S (2009). Utilization of growth promoters and bentonite sheep rations. Ph.D. Thesis Faculty of Agriculture Al-Azhar Univ.

Helal, F.I.S.; and K.A. Abdel-Rahmani (2010). Productive performance of Lactating ewes fed diets supplementing with dry yeast and /or bentonite as feed additives. World journal of Agricultural Sciences 6(5):489-498.

Kang, S.W.; J.S. Kim; W.M. Cho; B.S. Ahn; K.S. Ki and Y.S. Son (2002). Effect of domestic clay minerals on growth performance and carcass characteristics in growing, fattening Han woo steers. J. Anim. Sci. and Technology, 44(3): 327-340.

Kearl. L.C. (1982). Nutrient requirements of ruminants in developing countries. International feedstuffs Institute, Utah Agri. Expt. Stat. Utah State Univ., USA.

Kim Young, J; ; J. Woo-Whan; C. Tae-Ho and C. In-Hag (2017). Growth performance, meat quality, and carcass characteristics in growing and fattening Hanwoo steers fed bentonite. Acta. Scientiarum. Anim. Sci.Maringá,v. 39, n. 3, p. 309-313, July-Sept., 2017.

Kumar, D.S; Prasad, S.C; and R.M.V. Prasad, (2013). Effect of yeast culture (Saccharomyces cerevisiae) on ruminal microbial population in buffalo bulls. Buffalo Bulletin 32, 116-119.

Lee, S. M.; Y. I. Kim; and W. S. Kwak (2010). Effects of Dietary Addition of bentonite manure gas emission, health, production, and meat characteristics of Hanwoo (Bostauruscoreanae) Steers. Asian Australasian J. of Anim. Sci.,23 (12),1594-1600.

Mckenzie, R.A. (1991). Bentonite as therapy for Lantana Camarapoisoning .Austr. Vet. J. 68:146.

Milewski, S. (2009). Effect of yeast preparations Saccharomyces cerevisiae on meat performance traits and blood hematological indices in sucking lambs. Med Wet 2009; 65: 51-54.

Mohsen Kazemi, Morteza KhabbazSirjani, Abdoul Mansour Tahmasbi, Elias Ibrahimi Khoram Abadi and Ameneh Eskandary Torbaghan (2017). Effects of sodium and calcium bentonite on growth performance and rumen ammonia in Holstein bulls. Livestock Research for Rural Development 29 (8).

Mohsen, M. K.; and E.S. Tawfik (2002). Growth performance, rumen fermentation and blood constituents of goats fed diets supplemented with bentonite. (Kafr El-Sheikh ) Fac. of Agric. Tanta Univ.

Mousa, Kh. M.; O. M.; El-Malky, O.F.; Komonna, and S. E.; Rashwan (2012). Effect of Live Dried Yeast Supplementation on Digestion Coefficients, Some Rumen Fermentation, Blood Constituents and Some Reproductive and Productive Parameters in Rahmani Sheep. J. of American Sci. 8(2): 291303]. (ISSN:1545-1003). http://www.americanscience.org.42

Saleh, M. S.; E. M. Abd El - Raouf; M. K. Mohsen and A. Y. Salem (1999). Bentonite supplementation to concentrate ratio for lactating buffaloes. Egypt. J. Nutr. and Feeds; (2) Special Iss.: 67-78. 


\section{Ghoniem et al.}

Salem, F.A and A.A. El - Shewy (2001), Supplementation of bentonite and dolomite to lactating goats, rations. Egypt. J. Nutr. and Feeds, 4 (1): 11-20.

Salem, F.A.F.; H. El - Amary and S.H. Hassan (2001). Effect of bentonite supplementation on nutrients digestibility, rumen fermentation, some blood physiological parameters and performance of growing lambs. J. of Agric. Sci. Vol. 26-5, 3507-3517.

Sangmoo Lee; Youngil Kim and Wan-Sup Kwa (2010). Effects of Dietary Addition of Bentonite on Manure Gas Emission Health, Production, and Meat Characteristics of Hanwoo (Bostauruscoreanae) Steers. Asian-Aust. J. Anim. Sci. Vol. 23, No.12: 1594 -1600. Sci.,29: 777.

SAS (2003). SAS User's Guide: Statistics. Version 8.2, SAS Institute Inc., Cary, NC.

Van Keulen, J. and B.A. Young (1977). Evaluation of acid insoluble ash as natural marker in ruminant digestibility studies. J. Animal. Sci.,44: 2982.

Wan-Sup, K.; L. Sang-Moo and I.1. Young- Kim (2012). Effects of Dietary Addition of Bentonite and Probiotics on Meat wastes as fed supplement for growing goats under desert conditions.

\section{تأثير إضافة كل من الخميرة الجافة أو البنتونيت أو مخلوطهما كإضافات غذائية على أداء النمو للعجول الجاموس.}

الطبدالغتى حسانين غنيم وعلى احمد عبده على و عزت عرفة البلتاجى ورأفت ابراهيم معوض وعلاء الدين احمد حسن معه بحوث الإنتاج الحيوانس - مركز البحوث الزراعية ـ الدقى - الجبزة - مصر

أجريت الدراسة لتقييم تأثير إضافة الخميرة الجافة النشطة والبنتونيت و كليهما إلى علائق العجول الجاموس على الهضم وقياسات

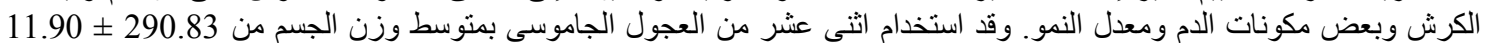

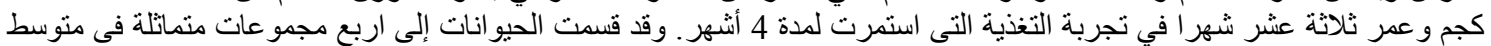

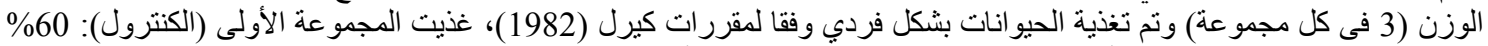

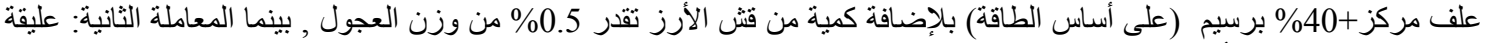

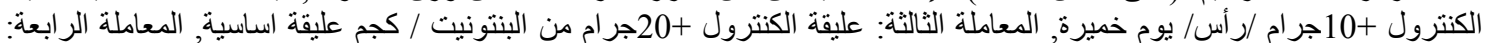

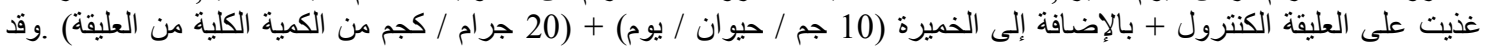

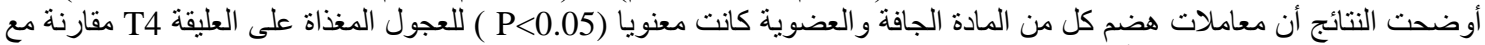

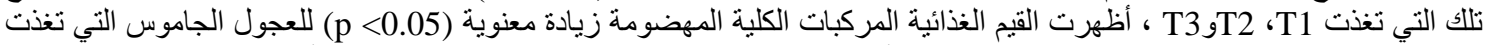

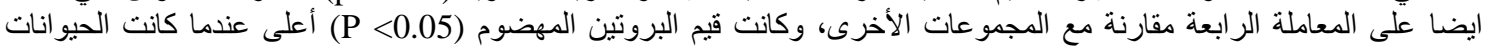

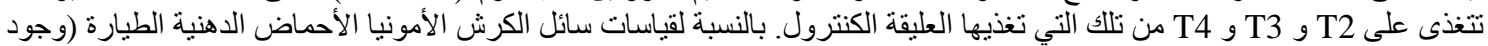

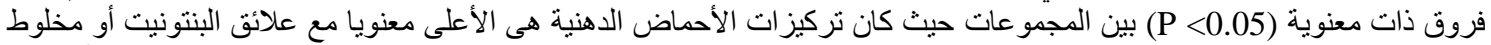

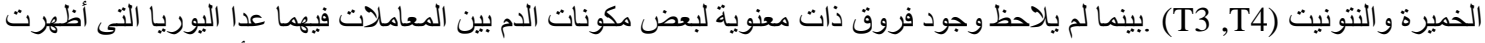

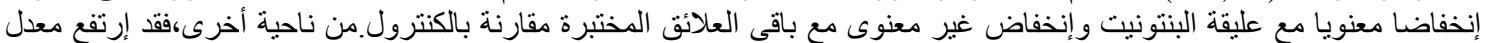

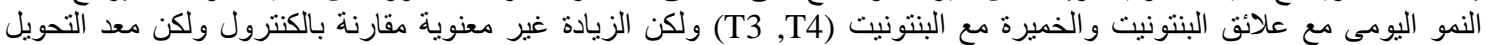

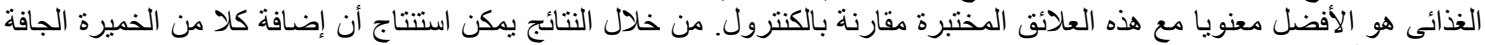

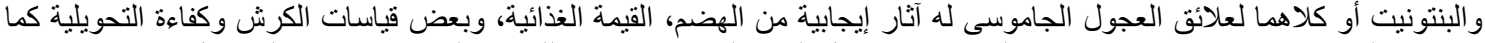

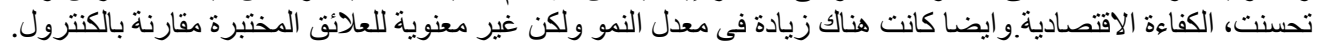

